\title{
Reverse Logistics and the Role of Fourth Party Logistics Provider
}

\author{
Roberta Pinna and Pier Paolo Carrus \\ University of Cagliari \\ Italy
}

\section{Introduction}

Conventional supply chain perspectives consider a set of processes, driven by customer demand, that convey goods from suppliers through manufacturers and distributors to the final customers. However, this is not where the story ends. Physical goods do not simply vanish once they have reached the customer. Nor does the value incorporated in them. Therefore, many goods move beyond the conventional supply chain horizon, thereby triggering additional business transactions: used products are sold on secondary markets; outdated products are upgraded to meet latest standards again; failed components are repaired to serve as spare parts; unsold stock is salvaged; reusable packaging is returned and refilled; used products are recycled into raw materials again.

The set of processes that accommodate these goods flows, which can often be interpreted as running 'upstream' in a conventional supply chain scheme, is known as reverse logistics. The OECD (2003) acknowledges that "Reverse logistics need to be developed. The imminent need in many countries to reduce, reuse and recycle waste will only become feasible with a transport system which carries used and returned goods for reuse and recycling (reversed logistics) in a cost-effective manner." 'The main reasons to become active in reverse logistics are different: environmental laws, economic benefits and the growing environmental consciousness of consumers. The result is an increase on reverse logistics activities on a whole range of industries, from the transport sector, consumer electronics, press and media to textiles and clothing, to mention just a few. As in the U.S., effective management of reverse logistics is still emerging in Europe and more and more firms now realize that the reverse logistics is a business process by itself and needs core competency to successfully manage it. As firms develop core competency in the fulfillment process, the core competency on the reverse logistics too may be difficult to attain for the same firm. Fortunately, there are specialized firms in the market now that have already developed core competency in many of the business processes involving reverse logistics, and are rapidly becoming the preferred outsourcing alternatives for the firms.

\section{Reverse logistics: Definition}

Reverse logistics (RL), a relatively new research direction in the area of supply chain management and logistics has gained increasing attention from academics and practitioners 


\begin{tabular}{|c|c|}
\hline Council of Logistics Management & $\begin{array}{l}\text { "...the term often used to refer to the role of logistics in } \\
\text { recycling, waste disposal, and management of hazardous } \\
\text { materials; a broader perspective includes all relating to } \\
\text { logistics activities carried out in source reduction, } \\
\text { recycling, substitution, reuse of materials and disposal." }\end{array}$ \\
\hline Pohlen and Farris (1992) & $\begin{array}{l}\text { "...the movement of goods from a consumer towards a } \\
\text { producer in a channel of distribution." }\end{array}$ \\
\hline Kopicky et al. (1993) & $\begin{array}{l}\text { "Reverse Logistics is a broad term referring to the } \\
\text { logistics management and disposing of hazardous or non- } \\
\text { hazardous waste from packaging and products. It } \\
\text { includes reverse distribution which causes goods and } \\
\text { information to flow in the opposite direction of normal } \\
\text { logistics activities." }\end{array}$ \\
\hline Kroon (1995) & $\begin{array}{l}\text { "are the logistic management skills and activities } \\
\text { involved in reducing, managing and disposing of } \\
\text { hazardous or non-hazardous waste from packaging and } \\
\text { products. It includes reverse distribution, which causes } \\
\text { goods and information to flow in the opposite direction } \\
\text { from normal logistic activities". }\end{array}$ \\
\hline Fleischmann et al. (1997) & $\begin{array}{l}\text { "a process which encompasses the logistics activities all } \\
\text { the way from used products no longer required by the } \\
\text { user to products again usable in a market". }\end{array}$ \\
\hline Krikke (1998) & $\begin{array}{l}\text { "is the collection, transportation, storage and processing } \\
\text { of discarded products". }\end{array}$ \\
\hline Dowlatshahi (2000) & $\begin{array}{l}\text { "a process in which a manufacturer systematically } \\
\text { accepts previously shipped products or parts from the } \\
\text { point for consumption for possible recycling, } \\
\text { remanufacturing, or disposal". }\end{array}$ \\
\hline Guide et al.(2000) & $\begin{array}{l}\text { "the task of recovering discarded products (cores); it may } \\
\text { include packaging and shipping materials and } \\
\text { backhauling them to a central collection point for either } \\
\text { recycling or remanufacturing". }\end{array}$ \\
\hline Rogers and Tibben-Lembke (1999) & $\begin{array}{l}\text { "The process of planning, implementing, and controlling } \\
\text { the efficient, cost-effective flow of raw materials, in- } \\
\text { process inventory, finished goods, and related } \\
\text { information from the point of consumption to the point of } \\
\text { origin for the purpose of recapturing value or proper } \\
\text { disposal." }\end{array}$ \\
\hline $\begin{array}{l}\text { European Working Group on } \\
\text { Reverse Logistics ( RevLog ) }\end{array}$ & $\begin{array}{l}\text { "The process of planning, implementing and controlling } \\
\text { flows of raw materials, in process inventory, and finished } \\
\text { goods, from a manufacturing, distribution or use point, } \\
\text { to a point of recovery or point of proper disposal". }\end{array}$ \\
\hline
\end{tabular}

Table 1. Definitions of Reverse Logistics 
(Blumberg, 1999; Carter and Ellram, 1998; Dowlatshahi, 2000; Rogers and Tibben-Lembke, 1999, 2001, 2002; Schwartz, 2000; Stock, 1998, 2001; Thierry et al., 1995, Van Hoek, 1999).Despite the popularity of the term reverse logistics, both in academia and practice, there remains considerable confusion as to its meaning. Such ambiguity suggests a need to examine the phenomena of RL more closely in order to clearly define the term and concept, to identify those factors that contribute to effective RL, and to suggest how the adoption of a RL approach can affect corporate strategy and performance.

If we analyze carefully these definitions most of the authors agree that they are basically discarded products, used products, products or parts previously shipped, hazardous and non-hazardous waste from packages and products, information, raw materials, in process inventory and finished goods. These inputs identify the scope of the RL process. Some of them limit the input to only waste or recycled products, but others allow a more wide concept where information, raw materials, inventories and goods are managed through the RL system. We believe this last consideration is more adapted to the RL concept, since it includes the entire "reverse flow" of things through the supply chain, and is not limiting the RL to either the waste management or the used products, which we think is a misleading and narrow vision of the RL concept, but as we can appreciate it is very commonly used. Most recently, according to the Reverse Logistics Association (2006), reverse logistics deals not only with returns processing but also with repair, customer service, parts management, end-of-life manufacturing and order fulfillment. The reverse logistics operations are different from the traditional logistics operations because the behavior of consumers introduces uncertainties in the quality, quantity, and timing of product returns (van Hillegersberg et al. 2001). The following are main characteristics of reverse logistics:

1. There is an uncertainty of returned time of a product.

2. There is an uncertainty of quality of a returned product, i.e. uncertainty of recovered value.

3. There is an uncertainty of configurations of parts or components of returned products.

4. There is an uncertainty of locations.

5. There is an uncertainty of amounts of recovered products

We would like to remark that Reverse Logistics is different from waste management as the latter mainly refers to collecting and processing waste (products for which there is no new use) efficiently and effectively. The crux in this matter is the definition of waste. This is a major issue, as the term has severe legal consequences, e.g. it is often forbidden to import waste. Reverse Logistics concentrates on those streams where there is some value to be recovered and the outcome enters a (new) supply chain. Reverse Logistics also differs from green logistics as that considers environmental aspects to all logistics activities and it has been focused specifically on forward logistic, i.e. from producer to customer (see Rodrigue et al., 2001). The prominent environmental issues in logistics are consumption of nonrenewable natural resources, air emissions,congestion and road usage, noise pollution, and both hazardous and non-hazardous waste disposal (see Camm, 2001). Finally, reverse logistics can be seen as part of sustainable development. The latter has been defined by Brundland (1998) in a report to the European Unionas "to meet the needs of the present without compromising the ability of future generations to meet their own needs." In fact one could regard reverse logistics as the implementation at the company level by making sure that society uses and re-uses both efficiently and effectively all the value which has 
been put into the products. Reverse Logistics also differs from green logistics as that considers environmental aspects to all logistics activities and it has been focused specifically on forward logistic, i.e. from producer to customer (see Rodrigue et al., 2001). The prominent environmental issues in logistics are consumption of nonrenewable natural resources, air emissions, congestion and road usage, noise pollution, and both hazardous and non-hazardous waste disposal.

\section{The driving forces}

In the literature of reverse logistics, many authors shows that a firm's reverse logistics activities are affected by intraorganizational factors, including a sincere commitment to environmental issues and succesfully implemented ethical standards, and the existence of policy entrepreneurs who make a strong commitment and take personal responsibility for organizational adoption od an environmentally friendly philosophy. The literature also indicates that a firm's reverse logistics activities are directly affected by one or more environmental forces: customers, suppliers, competitors and government agencie (Stock 1992; Pohlen and Farris, 1992; Barry and others, 1993; Kopichi and others, 1993; Livingstone and Sparks, 1994; Murphy and others, 1995; Cairnecross, 1992). The presence or absence of these factors can become drivers or barriers to reverse logistics implementation in a particolar industry. Knemeyer et al. (2002) propose a conceptual model that puts the various exogenous and endogenous factors together. Under this model, the external (or macro) environment or task environment may be defined as the specific organization or group that is relevant to goal setting and goal attainment, and that affects decisions, actions, and outcomes. It includes sectors with which the organization interacts directly and that have a direct impact on the organization's ability to achieve its goals: industry, competitors, customers, techniques of production, suppliers, stock market, raw materials, market sectors, government and perhaps the human resources and international sectors. Firstly, the government has the potential to control, legislate, or otherwise influence an organization's polizie and practices. Governments in developing countries have become increasingly concerned over the threat to human and environmental safety posed by end-of-life phones and other electronic products exported there for disposal. Internally, the firm must examine key strategic factors in designing its reverse logistic system, such as strategic costs, overall quality, customer service, environmental concerns, and legislative concerns, and operational factors, such as cost-benefit analysis,transportation, warehousing, supply management, remanufacturing, recycling, and packaging, that a firm must examine. These factors are critical and must be considered prior to operational factors. Strategic costs can include the costs of equipment for dismantling products, the cost for qualified workers to run the reverce logistics system, and the costo $\mathrm{f}$ additional warehous faciliries. These costs are considered strategic due to the need to allocate sufficient resources (financial and humans) to these initiatives (Stock, 1998) as opposed to the resources going to other areas of the company. Minimizing strategic costs depends on effective utilization of current resources, methods and technologies wich are essential for a succesful reverse logistics system. In relation to operational costs, these costs were dependent on both the input and output streams destre for the proposed system. Specifically, the strategic decision to place a heavier amphasis on refurbishing as opposed to recycling, the greater the costs associated with labor, transportation and warehouse facilities must be considered. The employees skills and the storage space requirements increase dramatically as the focus shifts to value added EOL 
products refurbishing. It is important to note that internal and external forces are not mutually exlusive. Without the external pressures, even the most savvy of policy entrepeneurs may not be able to convince others within the organization to become personally committed to the undertaking (Knemeyer et al., 2002). Conversely, without a policy entrepeneur to drive the program, stakeholder commitment, and an effective incentive system, the company may very well respond to external pressures by making only minor, cosmetic change to its systems rather than by implementino programs that are environmentally friendly. In fact, a greater understanding of organizational behavior can be gained by examining how organizations interact with their environment. Fig. 1 shows how external factors influences reverse logistics programs and activities. This conceptual model suggests that the external environment is comprised of four sectors:input, regulatory, competitive and output. The input sector represents an analysis of possible suppliers of products.

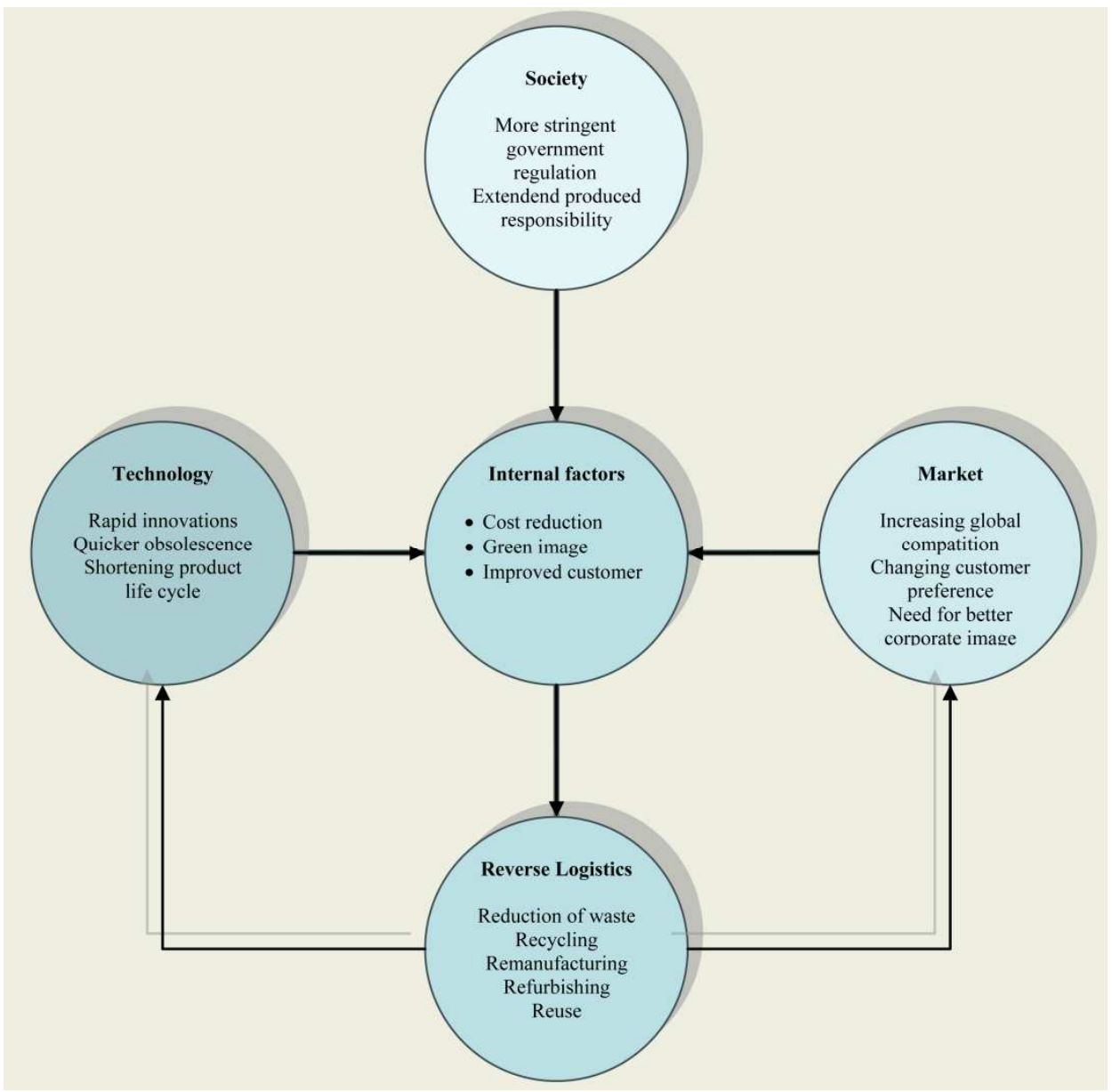

Source: Lau \& Wang (2009)

Fig. 1. The internal and external drivers of reverse logistics 
The regolatory sector esamine how governement and other external groups impact the system participants. The output sector focuses on the ultimate demand markets and, finally, the competitive sector addresses the level of competition within the sector. Within these sectors are key interorganizational partnerships including suppliers, competitors, government agencies and interested aggregators, such as consumer and lobbyng groups, which influence the governemnt and regulatory bodies. In particolar, we categorize the driving forces under three main headings:

- Economics

- Legislation;

- Corporate citizenship

Legislative, economic and social factors all contribute to an organisation's decision to adopt reverse logistics activities as part of their supply chain management processes. The following sections list some of the factors involved.

\subsection{Legislative factors}

Over the past few years, reverse logistics has been gaining increasing attention and awareness in the supplì chain community, both from practioners and researchers. This can be attributed to increate regulatory pressure such as estende producer responibility,partucularly in Europe, consumer expectations and societal sustainability demands, as well as to the intrinsic value that can be regained from collected products (De Brito, 2003). Lately, due to new waste management legislation (especially in Germany), the emphasis has been shifting towards recovery, due to the high costs and environmental burdens of disposal. Firms become more and more responsible for collecting, dismantling and upgrading of used products and packaging materials. The overall result is an increase on reverse logistics activities on a whole range of industries, from the transport sector, consumer electronics, press and media to textiles and clothing, to mention just a few. The management of return flows is becoming increasingly important for a growing number of businesses. Governmental policy and legislation, such as the WEEE Directive and environmental regulations restricting the disposal of potentially hazardous product and packaging materials, have forced manufacturers to take responsibility for the take-back of used goods from customer markets.

In Europe there has been an increase of environmentally related legislation, like on recycling quotas, packaging regulation and manufacturing take-back responsibility. The automobile industry and industries of electrical and electronic equipment are under special legal pressure (see Bloemhof et al., 2003). Sometimes companies partecipate "voluntarily" in covenants, either to deal with (or get prepared for) legislation. The UK Government promotes a "producer responsibility" policy which underlies the approach taken in implementing the EC Directives described below (Defra, 2006a). All these producer responsibility directives were identified in the European Union's Fifth Environment Action Programme as "priority waste streams" because of growing concern about their impact on the environment. In these Directives, responsibility is clearly placed on producers to bear the costs of collection, sortation or treatment and recycling or recovery. Such legislative actions can drive companies to utilise reverse logistics to recover products and certain types 
of waste from downstream supply chain stakeholders, and ensures the compliance with existing and future legislation (Bettac et al., 1999). The EC Directive on Packaging and Packaging Waste (94/62/EC) seeks to reduce the impact of packaging and packaging waste on the environment by introducing recovery and recycling targets for packaging waste, and by encouraging minimisation and reuse of packaging. The EC Directives on Waste Electrical and Electronic Equipment (WEEE) (2002/96/EC) and on the Restriction of the Use of Certain Hazardous Substances (RoHS) in Electrical and Electronic Equipment (2002/95/EC) aim to reduce the quantity and environmental impact of waste from electrical and electronic equipment and increase its reuse, recovery and recycling. The Directives affect producers, distributors and recyclers of electrical and electronic equipment, including household appliances, IT and telecoms equipment, audiovisual equipment (TV, video, hi-fi), lighting, electrical and electronic tools, toys, leisure and sports equipment. Increased recycling of such electrical and electronic equipment will limit the total quantity of waste going to final disposal. Producers will have responsibility for taking back and recycling electrical and electronic equipment. There is an incentive for manufacturers to design electrical and electronic equipment in an environmentally more efficient way, which takes waste management aspects fully into account (Europa, 2006). The EC End-of-life Vehicle (ELV) Directive (2000/53/EU) is concerned with cars, vans and certain three-wheeled vehicles. It aims to reduce the amount of waste from vehicles (cars and vans) when they are finally scrapped. In particular, it includes tightened environmental standards for vehicle treatment sites, requires that last owners must be able to dispose of their vehicles free of charge from 2007 (and requires producers to pay all or a significant part of the free takeback from this date), sets rising reuse, recycling and recovery targets and restricts the use of hazardous substances in both new vehicles and replacement vehicle parts. Another EC Directive which will impact on the transportation and other requirements of reverse logistics is the Directive on Distance Contract (97/7/EC), which stipulates that anyone who makes a purchase on the Internet or by phone, fax or via mail order is able to change their mind about the purchase during a "cooling-off" period of seven working days after the goods are received; no explanation for the rejection of goods is required. The onus of returning such goods is likely to lie with the potential customer, and many of these returned goods will be transported back to the original retailer or manufacturer by traditional delivery services. However, it is likely that more of these rejected items will be recovered through dedicated reverse logistics processes as they become more prevalent, particularly in response to the WEEE Directive.

\subsection{Economics factors}

The question whether product recovery is economically attractive or not has to be viewed within the legal framework in which the firm operates. However, as Buellens (2004) points out, a company that is considering adopting a reverse logistics or product recovery programme may be able to overcome any technical or legal difficulties, but might be dissuaded from adopting such processes due to the financial implications. Resources make reverse logistics programs more efficient and more effective, but there is recompense only when the resources are used in such a manner as to develop innovative capabilities/approaches to handling returns (Richey et al., 2005). Nevertheless, late entrants into reverse logistics have the advantage that they can utilise knowledge and experience 
from early adopters, and should be able to manage available resource in a more profitable way (Richey et al., 2004). However, the existence of a reverse logistics programme has been shown to bring direct monetary gains to companies by reducing the use of raw materials, by adding value with recovery, or by reducing disposal costs (Rogers et al., 2001; De Brito et al., 2003). Some other retail-related issues that reverse logistics can affect in a financially beneficial way are (DfT, 2004):

1. customer service - good returns policies may give a retailer an advantage over less liberal competitors;

2. effective inventory utilisation - removing old or slow-moving stock and replacing with newer, more desirable products can help promote sales;

3. recapturing product value - if unsold products can be quickly and effectively disposed of (for example, sold on by auction, or to Jobbers - someone who buys surplus or unwanted merchandise from one source, and profits by selling it on), some of the value may be reclame;

4. security of technology - by recovering all its own products, a company can prevent competitors accessing sensitive technologies, and thus may retain an advantage in the marketplace.

Even with no clear or immediate expected profit, an organization can get (more) involved with Reverse Logistics because of marketing, competition and/or strategic issues, from which are expected indirect gains. For instance, companies may get involved with recovery as a strategic step to get prepared for future legislation (see Louwers et al., 1999) or even to prevent legislation. In face of competition, a company may engage in recovery to prevent other companies from getting their technology, or from preventing them to enter the market. As reported by Dijkhuizen (1997), one of the motives of IBM in getting involved in (parts) recovery was to avoid that brokers would do that. Recovery can also be part of an image build-up operation. For instance, Canon has linked the copier recycling and cartridge recycling programs to the "kyo-sei" philosophy, i.e. cooperative growth, proclaiming that Canon is for "living and working together for the common good" (see Meijer, 1998; and, www.canon.com). Recovery can also be used to improve customer's or supplier' relations An example is a tyre producer who also offers customers rethreading options in order to reduce customer's costs. In sum, the economic driver embraces among others, the following direct and indirect gains:

- Direct gains:

- input materials;

- cost

- reduction;

- $\quad$ value added recovery;

- Indirect gains:

- $\quad$ anticipating/impeding legislation

- market protection;

- green image;

- improved customer/supplier relations;

Properly and thoroughly executed RLA significantly improve bottom-line performance. Certain value is inherent to well-managed RL: for finance, operational cost controls and 
asset recovery; for sales, increased customer satisfaction; and for quality, valuable customer data which can lead to product design improvements. Enhanced custode service, improved customer satisfaction, increased control of inventory, reduced costs, higher profitability, and enhancement of corporate image have all been identified as potential benefits that firms with effective RLA may enjoy. Product recovery can also be a part of an image-building operation or can be used to improve the relationship with a customer or supplier.

\subsection{Social factors and extended responsibility}

"Extended Responsibility", or "Corporate Citizenship" concerns a set of values or principles that drive an organisation to become responsibly engaged with particolar activities, including reverse logistics. The extended producer responsibility is that producer must be responsible for the whole life cycle (including production process and life ending stage) of production made by themselves, and particularly recovery, and recycle, reproducing, reuse of the end of lofe product, in order to realize the recycling resources and the purpose of environmental protection. Extended producer responibility has now almost become a norm for all large International enterprises particularly in the electronic and auto motive industry. In 1997, Europe Union formally come on the statute of Re cycling of the electrician and electronics products, which rule every manufactory or importer of marketing the electrician and electronics products into European market must recover and remanufacture and reuse the EOL (the end of life) products caused by marketing, so that the concept of extended producer responsibility was put forward. Nowaday, the green image has been increasingly recognized a san important marketing element and can improve customer relations. Many compagnie now have extensive programs on responsible corporate citizenship where both social and environmental issues become the priorities.

\section{Different type of returns}

The high level of uncertainty arisen as a result of the different characteristics in terms of quantity and quality of the returned products, makes more complicated the production planning task and increases the complexity of the inventory control process. A good way to understand this uncertainty is to analyze the most common causes of products' return. The reasons for products being returned are discussed by a number of authors. De Brito et al. (2003) categorise returns under three headings:

a. Manufacturing returns - raw material surplus, quality-control returns, production leftovers or by-products;

b. Distribution returns - product recalls, commercial returns (unsold products and wrong or damaged deliveries), stock adjustments, functional returns (distribution items, carriers, packaging);

c. Customer returns - reimbursement guarantee returns, warranty returns, service returns, end-of-use, end-of-life returns.

Rogers and Tibben-Lembke (1998) describe the principal causes for which the people return the products. Table 2 shows the common causes of products'returns. Manufacturing returns as all those cases where components or products have to be recovered in the production 
phase. This occurs for a variety of reasons. Raw materials may be left over, intermediate or final products may fail quality checks and have to be reworked and products may be left over during production, or by-products may result from production. Raw material surplus and production leftovers represent the product not-needed category, while quality-control returns fit in the "faulty" category. Distribution returns refers to all those returns that are initiated during the distribution phase. It refers to product recalls, commercial returns, stock adjustments and functional returns.

Product recalls are products recollected because of safety or health problems with the products, and the manufacturer or a supplier usually initiates them. B2B commercial returns are all those returns where a retailer has a contractual option to return products to the supplier. This can refer to wrong/damaged deliveries, to products with a too short remaining shelf life or to unsold products that retailers or distributors return to e.g. the wholesaler or manufacturer. The latter include outdated products, i.e.those products whose shelf life has been too long (e.g. pharmaceuticals and food) and may no longer be sold. Stock adjustments take place when an actor in the chain re-distributes stocks, for instance between warehouses or shops, e.g. in case of seasonal products (see De Koster et al., 2002). Finally, functional returns concern all the products which inherent function makes them going back and forward in the chain. The third group consists of customer returns, i.e. those returns initiated once the product has at least reached the final customer.

\begin{tabular}{|c|l|l|l|}
\hline & Manufacturing return & \multicolumn{1}{c|}{ Distribution returns } & \multicolumn{1}{c|}{ Customer returns } \\
\hline \multirow{2}{*}{} & $\begin{array}{l}\text { Raw material surplus, } \\
\text { quality-control } \\
\text { returns, production } \\
\text { leftovers }\end{array}$ & $\begin{array}{l}\text { Unsold products and wrong } \\
\text { or damaged deliveries, stock } \\
\text { adjustments, functional } \\
\text { returns }\end{array}$ & $\begin{array}{l}\text { Defective/ unwanted } \\
\text { products, recalls, end-of- } \\
\text { use, end-of-life returns., } \\
\text { service returns }\end{array}$ \\
\hline
\end{tabular}

Source: Adapted from Rogers et al. (1999)

Table 2. Common causes of products' return

\section{Recovery options and reverse logistics activities}

Once a product has been returned to a company, the firm has many disposal options from which to choose: 1) direct re-use (and re-sale); 2) product recovery management (repair; refurbishing; remanufacturing; cannibalization; recycling); and 3) waste management (incineration and land filling).

If the product can be returned to the supplier for a full refund, the firm may choose this option first. If the product has not been used, it may be resold to a different customer, or it may be sold through an outlet store. If it is not of sufficient quality to be sold through either of these options, it may be sold to a salvage company that will export the product to a foreign market. If the product cannot be sold "as is," or if the firm can significantly increase the selling price by reconditioning, refurbishing or remanufacturing the product, the firm may perform these activities before selling the product. After performing these activities, the 
product may be sold as a reconditioned or remanufactured product, but not as new. If the product cannot be reconditioned in any way, because of its poor condition, legal implications, or environmental restrictions, the firm will try to dispose of the product for the least cost. Any valuable materials that can be reclaimed will be reclaimed, and any other recyclable materials will be removed before the remainder is finally sent to a landfill. The main reverse logistic processes are the following (see Figure 2):
a. Collection;
b. Examination and processing;
c. Re-processing or direct recovery;
d. Redistribution

The first stage in the process is collection, that is, all those activities that are necessary for reclaiming returned products, surplus or by-products and transporting them to a point of recovery where they will be subjected to further examination and processing i.e. their quality is assessed and a decision is made on the type of recovery. This issue is central at the stage of inspection/selection and sorting, $\mathrm{w}$ h e re a decision must be reached as to whether a product (or parts of it) will be re -used, remanufactured, recycled or disposed. Physical inspection is necessary for determining further processing for most commercial products.

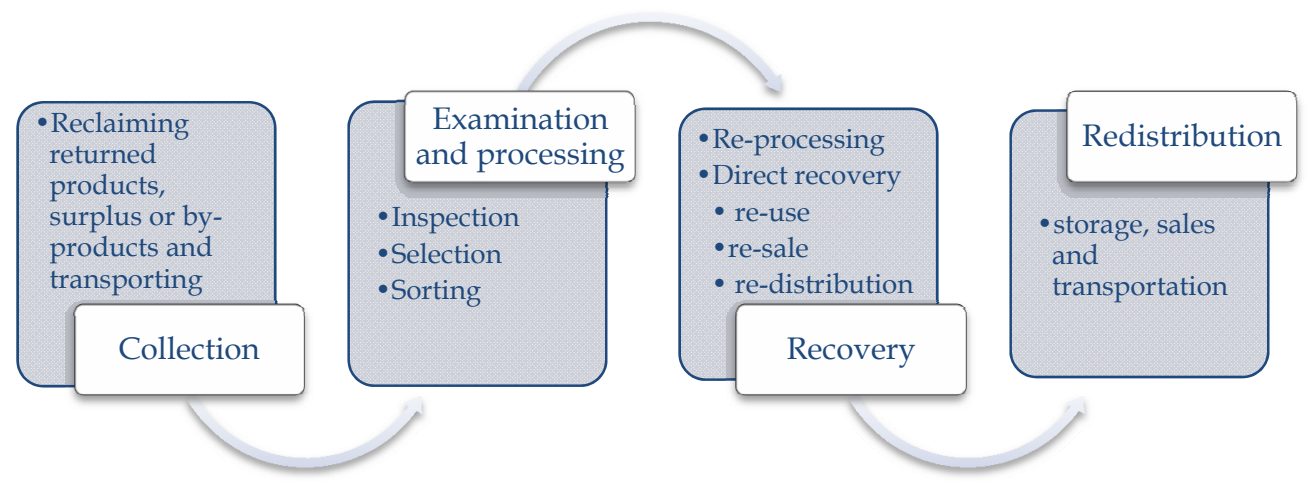

Fig. 2. Main reverse logistic processes

The third process is the recovery. Once a product has been returned to a company, the firm has many disposal options from which to choose. If the quality is "as-good-as-new," products can be fed into the market almost immediately through direct recovery. Direct recovery involves three options: re-use; re-sale and re-distribution . Re-use refers to cases where returned products have such a good quality that they can be re-used almost immediately in the same or an alternative market. This happens for re-usable bottles, containers and most leased or rented equipment. Re-use is a situation in which the product is used again, but there is no purchase, e.g. unse spare parts. Re-sale applies to situations 
where the product is sold again. Finally, re-distribution refers to products like carriers, that are simply distributed again and again. The second option is the re-processing that includes the following recovery options:

- repair (at product level),

- refurbishing (at module level),

- remanufacturing (at component level),

- retrieval (at part level),

- recycling (material level), and

- incineration (energy level).

At module level, the product, e.g. a large installation, building or other civil object gets upgraded (refurbishment). In case of component recovery, products are dismantled and used and new parts can be used either in the manufacturing of the same products or of different products (remanufacturing). In material recovery, products are grinded and their materials are sorted out and grouped according to a quality wish, so recycled materials can be input raw material, such as paper pulp and glass. Finally, in energy recovery products are burned and the released energy is captured (incineration). If none of these recovery processes occur, products are likely to go to landfill.

Finally, re-distribution refers to logistics activities required to introduce a product into a market and transfer it to customers (i.e. storage, sales and transportation).

Figure 3 shows a schematic of a typical supply chain, with the inclusion of the recovery process.

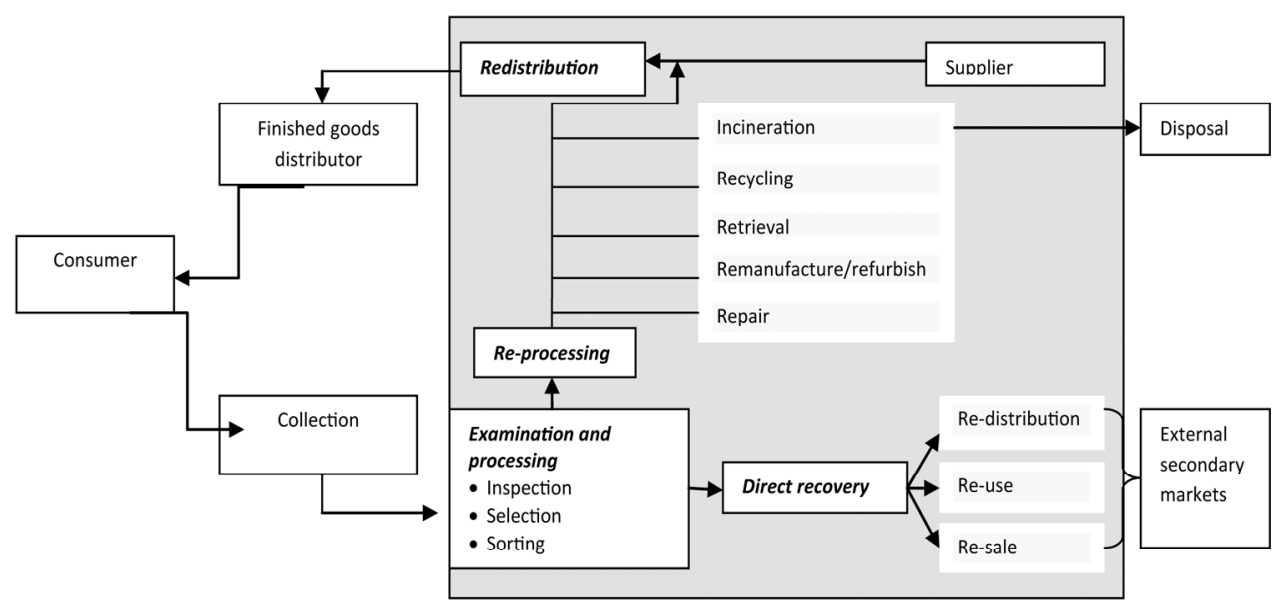

Source: adapted from Srivastava (2008)

Fig. 3. Reverse flows in the supply chain 


\section{Managing product returns and organizational design}

The organizational implications of RL management concerns what kinds of inter-firm relationships are relevant. Halldórsson and Skjøtt-Larsen (2007) identify the two reverse supply chain 'extremes' - at one extreme, there is the centralized reverse supply chain, whereby one organisation has responsibility for collection, inspection, disposition and redistribution of returned items. At the other extreme is the decentralized reverse supply chain, which consists of multiple organizations involved in all these processes. Between the two extremes are various hybrids. The reverse flows management requires planning, managing and controlling these flows through the integration of key processes, from consumers to the original suppliers. Mentzer et al. (2001) identify three degrees of supply chain complexity: a "direct supply chain," an "extended supply chain," and an "ultimate supply chain." A direct supply chain consists of a company, a supplier, and a customer involved in the upstream and/or downstream flows of products, services, finances, and/or information. An extended supply chain includes suppliers of the immediate supplier and customers of the immediate customer, all involved in the upstream and/or downstream flows of products, services, finances, and/or information. An ultimate supply chain includes all the organizations involved in all the upstream and downstream flows of products, services, finances, and information from the ultimate supplier to the ultimate customer (Figure 4).

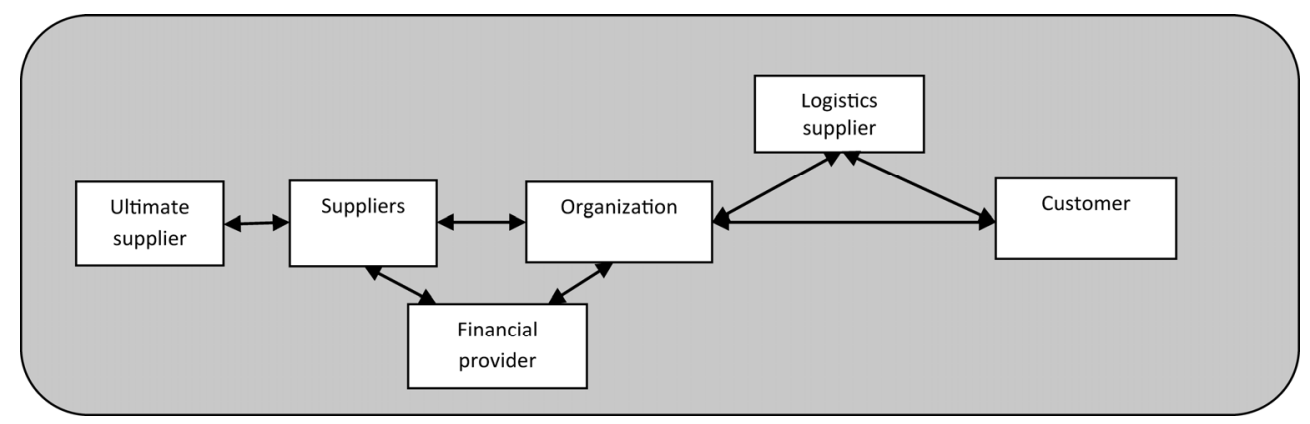

Source: Mentzer et.al. (2001)

Fig. 4. Channel relationships

Companies are responding to the challenges, in particular through a focus on:

- $\quad$ building greater value for their customers and shareholders;

- integrating traditionally distinct business functions across the entire business network;

- developing distinctive capabilities around their relationships with their trading partners, the design of information systems, and the re-structuring of their business models.

The companies have started to work more collaboratively with their suppliers and logistics partners in order to provide a seamless service to their customers. This trend has brought about the adoption of a new and more complex business model that includes coordination and collaboration with channel partners, which can be suppliers, intermediaries, third-party 
service providers, and customers. These companies are interdependent in such a way that an individual company's performance affects the performance of other members of the supply chain.

\section{Outsourcing reverse logistics: The role of fourth party logistics provider}

According to Berglund et al. (1999) two factors lead companies to outsource: the size of the demand and the size of the supply chain. In an adaptation of the topics suggested by Bolumole (2001) and Jaafar and Rafiq (2005), below is shown a summary of the motivations and reasons for a company to outsource logistics services:

- Concentrating efforts on their own business and gaining new markets;

- Reducing logistics costs and avoiding investments in assets unrelated to the company's business;

- The presence of a complex supply chain due to a fragmented suppliers base;

- Increasing product restitution (reverse logistics);

- Coordinating logistics activities in a wider context;

- Improving and controlling the quality of logistics services and activities;

- Greater flexibility and efficiency in logistics operations;

- Access to new Information and Communication Technology (ICT) and logistics knowledge.

Langley et al. (2007) asserted that, by incorporating new activities required by the market, the LSP has changed in recent years, a movement that demonstrates the progress and maturity of these operators. However, clients expect to achieve greater skills in service development, relationship improvements, relevance in information and involvement of integration rules and concepts in the supply chain through the LSP, and to build expertise and dedicated operations. Likewise, for these authors, the market turns to solutions proposed by companies focusing on logistics coordination. The following are expectations for the LSP:

- Evolve into a solution provider for the supply chain;

- Increase the portfolio of outsourced services through a larger number of activities (expand services for its clients)

- Continuous improvement in technology and ability to provide the necessary services;

- Focus on the client's needs (provide the right solutions, become involved in the client's plans for integration and understand the industry-client)

- Expand its relationship with the client;

- Continue to acquire companies and expand businesses;

- Act in global markets;

- Move toward logistics coordination solutions as a 4PL;

- Search for long term relationships, based on contracts with duration exceeding two years.

As the practice of reverse logistics outsourcing and SCM have become increasingly important as a source of competitive advantage, researchers have started to explore various research topics related to reverse logistics outsourcing and the role of specialized reverse chain players (Carter and Ellram, 1998; Sanders, 2005). Increasingly, as a strategy, to 
compete on services, companies offer repair and replacement services for their products under the warranty periods. The defective products are often shipped across international borders to common repair centers to be refurbished and returned to the originating station. Logistics service providers who offer these services have to tackle issues pertaining to duty payment on refurbished products, customs documentation and the establishment of collection points for repair for the customers.

The outsourcing of an increasing number of logistics activities to Logistics Service Providers (LSP) is a growing trend and business practice followed world wide by the industry. The outsourcing of logistics activities can be defined in three levels, the transactional outsourcing, the tactical outsourcing and thestrategic outsourcing. The transactional outsourcing is based on logistics transactions, with no long-termcontracts and no bonding between the Logistics Service Providers (LSP) and the outsourcing company. The tactical outsourcing is the logistics reinforce and improve the network's performance. Such logistics activities are, for instance, transportation, inventory management, storage, material handling, packaging, production planning, information processing, facility location, purchasing, demandforecasting, customer service, and design, redesign and control of the logistics network outsourcing on a long-term basis with negotiated contacts and integrated IT systems to facilitate freeinformation flow and create supply chain visibility. The strategic outsourcing is based on long-term relationships with successful outcomes where LSP business entities become partners with their clients in the logistics-network management and establish transactional transparency.

More and more firms now realize that the reverse logistics is a business process by itself and needs core competency to successfully manage it ( Lieb, R. and Bentz, B.A., 2003). As legislation such as the WEEE directive comes into force, and organizations have to be able to deal an increasing volume and variety of returns. There are opportunities for the small and medium firms to cooperate with other organizations to create sufficient volume to justify the developmente of reverse logistics programmes. As firms develop core competency in the fulfillment process, the core competency on the reverse logistics too may be difficult to attain for the same firm. Fortunately, there are specialized firms in the market now that have already developed core competency in many of the business processes involving reverse logistics, and are rapidly becoming the preferred outsourcing alternatives for the firms (Verstrepen S., et.al.,2007). According to John Gattorna, "While outsourcing third-party logistics is now an accepted business practice, $4 \mathrm{PL}$ is emerging as a breakthrough solution to modern supply chain challenges...to provide maximum overall benefit". The concept of Fourth-Party Logistics (4PL) Provider was created and first defined in 1996 by Accenture as the use of a consulting firm to integrate and manage a company's logistics resources and LSP partners including Third-Party Logistics (3PL) providers and other transportation companies. In particular, Accenture defined a 4PL Service Provider as an integrator that assembles the resources, capabilities and technology of its own organization and other organizations, to design, build and run comprehensive logistics network solutions. FourthParty Logistics (4PL) providers, who, in addition to the classic 3PL operations can manage all of the "information systems" interfaces needed to mobilise all of the resources of the upstream (suppliers) and downstream (distributors, service providers) actors involved in the e-supply chain. 
The 4PL are companies which have no physical assets of their own but specialize in buying and coordinating logistics. Andersen Consulting defined a Fourth-Party Logistics Providers as: "A supply chain integrator who assembles and manages the resources, capabilities, and technology of its organization with those of complementary service providers to deliver a comprehensive supply chain solution." Central to the 4PL success is a "best of breed" approach to providing services to a client. The development of 4PL solutions leverages the capabilities of third-party logistics providers, technol-ogy service providers, and business process managers to create a solution through a centralized point of contact. As a result, 4PLs have become logical alternatives for business process outsourcing by providing visibility and integration across multiple enterprises. Users of a $4 \mathrm{PL}$ can focus on core competencies to better manage and utilize company assets and resources, as to inventory and personnel. There are only a few studies in the literature that examine the role of $3 \mathrm{PL} / 4 \mathrm{PL}$ in reverse logistics. Some autors pointed out that the use of specific technological capabilities may facilitate more effective integration across companies in the sup-ply chain (Van Hoek 2002). For 4PLs, ICT capabilities can assure the rapid customisation of products and maintain competitive lead-times. Mukhopadhyay and Setaputra (2006) provide a a model to develop optimal decision polizie for seller and 4PL. Information and communication technology (ICT) has become an important element of 4PLs competitive capability as it enables higher levels of reverse logistic integration. Specifically, the type of IT used largely determines the nature and quality of interactions the company has with customers, suppliers, and trading partners. A high level of IT capability has been shown to provide a clear competi-tive advantage and can be a differentiating factor in terms of company perfor-mance (Earl, 1993; Kathuria et al., 1999). The result is that competitive advantage in the 4PL industry will be based increasingly on creating value for customers as many value-added activities are directly or indirectly dependent on ICT applications (Crowley, 1998). The development of 4PL(TM) solutions leverages the capabilities of thirdparty logistics providers, technology service providers, and business process managers to create a solution through a centralized point of contact. For exemple, in Italy CCR Italia is a reverse logistic service provider located in Torino, and it is a specialist in the development and implementation of Europe-wide reverse logistics solutions for products, components and materials with a focus on B2B solutions. The company operate in the Italian market as a "solution integrator" that manages an integrated reverse logistics processes (recycling, landfilling and reuse) for a single client, and coordinate a complex network in which the 4PL combines the resources and capabilities of several third party logistic provider (Fig.5 ). A $4 \mathrm{PL}$ is treated as a strategic partner, rather than a tactical one and is a supply chain integrator that synthesizes and manages the resources, capabilities, and technology of its own organization with those of omplementary service providers to deliver a comprehensive supply chain solution. The 4PL Service Provider is an external organization which completely integrates its client's logistics network. Planning and management of the total logistics network are put into hands of an external company that acts as the single contact between the client and the 3PL Service Providers.

The core value offered by a $4 \mathrm{PL}$ firm is in the management and integration of the information flow between the outsourced logitics-network partners and the enterprises that employ them. By taking care of the planning, steering and controlling of all logistics procedures, the Fourth-Party Logistics (4PL) Service Provider is able to combine the 
economy of skill with the economy of scale. Fourth-Party Logistics (4PL) is the next generation of LSP firms, with operations that extend beyond 3PL and include logisticsnetwork analysis, design and planning. While the present logistics activities provided by a 3PL service provider simply include the coordination of the distribution from one place to another, 4PL providers make possible for the companies to develop a superior expertise in transportation, warehousing and other logistics fields. 4PL companies are suppliers which have the expertise to manage resources, value delivery processes and technology for their clients in order to allow their clients to totally outsource their logistics management activity. The 4PLs do not compete with 3PLs as they have superior expertise in their respective fields by virtue of their investment and specialization. 4PL providers do not own assets for transportation or warehousing, but rather leverage the solutions created by 3PL, in order to identify and provide 'best in class' services to their clients.

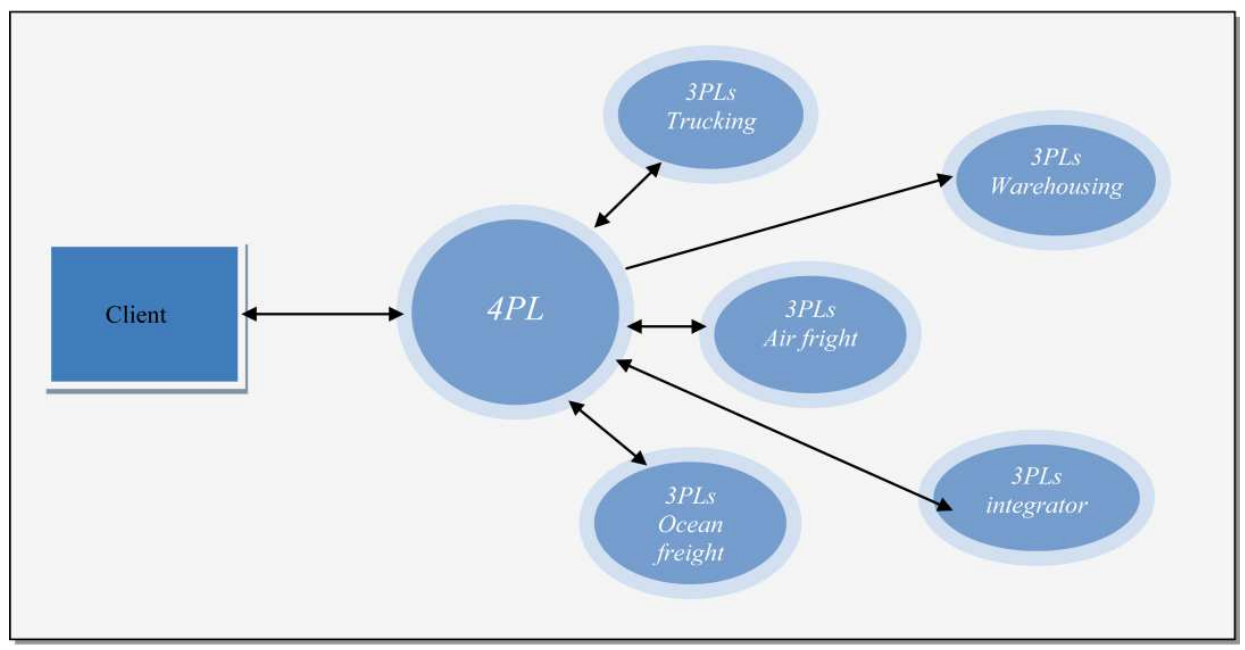

Fig. 5. 4PL as a solution integrator

There are many variations of the $4 \mathrm{PL}$ model that are practiced. Three different models are summarized as under:

a. Lead logistics provider: The 4PL provider acts as an in house freight management company, it might or might not have a role in the selection of 3 PL partners. It takes care of transport invoicing and the monitoring of the performance of the 3 PLs;

b. Solution Integrator: In this variant of the model, the 4PL acts as the integrator of various 3PLS and as a single window for freight negotiations, 3PI selection and freight management on behalf of its client;

c. Industry Innovator: Under this model the 4PL uses its expertise and resources to create a solution not for any single client, but for offering $4 \mathrm{PL}$ services to a number of clients in an industry.

The services provided by a 4PL provider are show in table 3. The 4PL Service Provider integrates 3PL Service Providers together with IT Service Providers supporting simultaneously and managing its clients' business processes. A 4PL actor can achieve 
greater logistics functional integration and broader operational autonomy managing its clients' logistics networks from upstream todownstream and from a holistic perspective.

\begin{tabular}{l|l|l|l|}
\hline \multirow{2}{*}{$\begin{array}{l}\text { Physical Services } \\
\text { Administrative }\end{array}$} & \multicolumn{1}{|c|}{ Basic } & \multicolumn{1}{|c|}{ Intermediate } & \multicolumn{1}{c|}{ Advanced } \\
\cline { 3 - 4 } & $\begin{array}{l}\text { None } \\
\text { Tendering \& } \\
\text { contracting carriers } \\
\text { Insurance services }\end{array}$ & $\begin{array}{l}\text { None } \\
\text { Payment services } \\
\text { Financial services } \\
\text { Order } \\
\text { administration \& } \\
\text { customer service } \\
\text { Claims handling } \\
\text { individual logistics } \\
\text { setup } \\
\text { Operation of } \\
\text { customers' logistics } \\
\text { setup } \\
\text { Track and trace } \\
\text { information }\end{array}$ & $\begin{array}{l}\text { Responsible for the } \\
\text { customers' logistics } \\
\text { oparations } \\
\text { Exception } \\
\text { management }\end{array}$ \\
& $\begin{array}{l}\text { Providing one stop } \\
\text { logistics services } \\
\text { purchase } \\
\text { Export and import } \\
\text { clearance }\end{array}$ & \\
\hline
\end{tabular}

Table 3. 4PL Services

The outsourcing of logistics activities requires creating synergetic relationship between the partners with the objective of maximizing customer value and providing a profit for each supply chain member. Coordination within a supply chain is a strategic response to the challenges that arise from these dependencies. There is a growing body of academic research, in a variety of disciplines, on coordination in supply chains, particularly addressing the potential coordination mechanisms available to eliminate sub-optimization within supply chains. Similarly, there is a growing interest in industry to better understand supply chain coordination and the coordination mechanisms that are available to assist the supply chain manager.

\section{Reverse logistics information systems and 4PL capabilities}

The new operating environment and the emergence of the extended enterprise model present many logistical challenges.Two particolar forces are at work in the evolving operating environment for supply chains. On the one hand, new technology is enabling the more rapid adoption of true supply chain integration within companies and collaboration across the supply chain of multiple companies. But on the other In particular, they note that information needs to cross organizational boundaries in order to support management decision-making. From the perspective of integrated supply chain management, it is necessary to establish a total supply chain network with an integrated database capable of supporting each activities and processes (Bardi, Raghunathan, and Bagchi 1994). Thus, information support is particularly critical to achieving efficient reverse logistics activities. 
Bowersox (1989) proposes that the process of supply chain integration should progress from the integration of internal logistics processes to external integration with suppliers and customers. Internal and external integration can be accomplished by the continuous automation and standardization of each internal logistics function, and by efficient information sharing and strategic linkage with suppliers and customers. Major element in supporting this new business model is the timely availability of relevant information made available through the exploitation of information systems (IS). Reverse logistics is frequently characterized by uncertainty and a need for rapid timing/processing. While some industries can rely upon historical information to project the type and amount of returns, returns in other industries are much less easy to predict. Even in those less predictable industries, although managers may not know when products will be coming back, they must be prepared to quickly process and handle the products on demand. Thus, prompt and accurate exchange and access to information should be considered a top priority. So despite the open access to new technology and the increate availability of information, which are the lifeblood of reverse logistics integration, relatively few companie have improved their integration and collaboration capabilities across supply chain.

In such situations, information coordination is complicated because different are the actors involved. As Blumberg (1999) notes, there is great need for coordination between the parties to ensure maximum efficiency. Communication becomes particularly critical to facilitate daily interaction and to promote longer-term business relationships. The flexibility of a company's transaction processing system, the capability to transfer and gain access to information, and the real-time visibility of operational data are also essential elements in building the extended enterprise business model.

Rapid developments in information technology (IT) have many implications for the organization and management of the reverse logistics networks and offer the potential for businesses to exchange and share such information in real-time. The Internet, in particular, is providing an opportunity for companies to lower costs dramatically across the extended enterprise. The Internet, however, needs to be seen as part of the infrastructure supporting the integration of the extended enterprise. Several information systems (e.g. EDI, RFID and GPS14) are needed and can support the control and decision-making upon the efficiency and effectiveness of the modern logistics networks.

The IS provided by Fourth-Party Logistics (4PL) Service Providers mainly assist the participating actors throughout the logistics network to develop functional and technical requirements for logistics information systems incorporating logistics database design, customer response systems, inventory management systems, supply and production management systems, transportation management systems, warehouse management systems (e.g. WMS), and supporting logistics decision support tools.

Information and communication technology (ICT) has become an important element of 4PLs competitive capability as it enables higher levels of supply chain integration. Sauvage (2003) noted that in a highly competitive business characterised by time compression, technological effort becomes a critical variable and a significant tool for differentiation of logistics services. Its technological capacitation is also essential for the implementation and integration of services. Thus, technological support for data transfer and transactions has become a powerful tool for the LSP. With up-to-date information and communication 
technology, new configurations are presented for logistics management by the LSP, as several authors suggest (Hoek, 2006; Langley and Allen, 2005; Visser et al., 2004) when defining 4PLs as integrators or logistics leaders in a coordinating function that is broader than a simple operation. Specifically, the type of IT used largely determines the nature and quality of interactions the company has with customers, suppliers, and trading partners. For 4PLs, ICT capabilities can assure the rapid customisation of products and maintain competitive lead-times. The result is that competitive advantage in the 4PL industry will be based increasingly on creating value for customers as many value-added activities are directly or indirectly dependent on ICT applications (Crowley, 1998).This means information must be continuously accessible and shared across organizations. Such information support is a critical aspect of reverse logistics. ICT systems developed for the control and coordination of reverse logistics processes assist in the decision making for the recovery options of returns (reuse, remanufacturing, recycling) and support administrative tashs related to returns handling that contribute to more efficient returns management. Readly available abd accurate informations provide necessary support for accommodating non routine events such as product returns. Information support helps to reclaim value that might otherwise be lost and it also serves to improve buyer-seller relationships through improved customer service/satisfaction. IT allows supply chain partners to communicate directly over data-rich, easy to use information channels, which reduces coordination costs faster than in house production costs and promotes the trend toward outsourcing. In general it is important to know what product will be returned at which point in time at which place, in which conditions and under what grounds. Electronic Data Interchange (EDI) allows trading partners to Exchange information electronically in a very compact, concise and precise way and it provides different transaction sets for various types of business activities. One result of this development is CCR NET, a web-based order and documentation system developed by CCR that illustrates virtually the logistical process chains of industrial goods in the real world. Web-technologies to offer unique services for handling returns. For the customers, a large number of reports are available for downloading at any time. A range of operational performance and inventory data may be filtered according to different criteria, displayed and downloaded in the standard data formats (Excel, HTML, PDF and others), in line with individual requirements. CCR NET allows the cus-tomers different user roles - like, for instance, the overall view, but also partial views down to the smallest unit imaginable - in order to take account of the inter-nal structures of our customers. On the basis of CCR NET, the provider's specialists assemble the necessary documentation (as specified by legislation on waste disposal) for internal verification and for the authorities. Verification may take place via reports, or via electronic interfaces to the IT systems of its customers and the authorities. For example, this includes waste balance sheets, substance flow proofs, recycling quotas and individual verifications, and even weight forms or in-dividual delivery documents. Within the clearing functionalities, money and material flows may be directed according to the individual requirements of customers. This includes payments to consumers or commercial businesses for deposits or material values which are transferred by CCR on the order of the customers. The customers decide on the type or characteristics of their deposit or bonus sys-tems, according to their objectives; CCR for its part organises the flows of mate-rials, information and money by means of its comprehensive reverse logistics sys-tems. Those receiving payments are, as a rule, also integrated into the circulation of information via CCR NET, and 
can pursue and monitor their entitlements and incentive bonuses there, by means of appropriate reports. The provider confirmed that its IT solutions allow effective information sharin with clients, increase transparency, safety and efficiency in the return processes. One of the first visible effects associated with the increasing dissemination of ICT in the CCR reverse logistics service is the integration of traditional reverse logistics activities with information-based services. The linking of data-streams and the prompt review of goods transport processes in an electronic data processing system are becoming more and more important for the optimisation of monitoring and control functions, but also in ensuring transparency and safety and lower coordination costs. It maps all the relevant data of a reverse logistics process and involves all those taking part. Having developed it selves brings the enormous advantage that the provider can offer competent and efficient customer-specific solutions and undertake tailor-made adaptations. Thanks to skilled technical and information system solutions the company allowing the customers to: close integration with the customer's processes and IT systems; securing and uti-lising secondary resources, thus strengthening the company's environmental and social responsibility; facilitates access to new markets and supports sales revenues; reduce handling of products; improve performance efficiency; greater flexi-bility; reducing communication errors, better visibility and customer satisfaction.

However, effective fast cross organizational sharin of information is possible if information systems are compatible, such a sit refers to how easy it is to use. In a reverse logistics context, this would means that channel members' information systems must be compatible, i.e., in agreement. IS support compatibilità implies the existence of congruent systems that facilitate Exchange between separate organizations. Chapman et al. (2003) reported that logistic organizations are redesigning their structures and relationships, creating a knowledge chain that facilitates and improves data, information and knowledge communication, as well as coordination, decision-making and planning. They should mainly synchronize activities between agents of the supply chain (aiming to gain and integrate knowledge) and operate with information and communication technology, thus providing greater efficiency and productivity for the chain. Ratten (2004) highlighted that many logistics alliances have been made based on technological changes, and improved data transmission and transactions. In this case, alliances with companies of the technology sector may be necessary for the LSP.

\section{Conclusion}

The exchange of information through customers and 4PL is an essential condition for realizing the potential benefits of collaborative relationships (performance). ICT systems developed for the control and coordination of reverse logistics processes assist in the decision making for the recovery options of returns (reuse, remanufacturing, recycling) and support administrative tasks related to returns handling that contribute to more efficient returns managemen. The increased speed and flexibility of information and knowledge transfer allowed for more efficient coordination, and eventually higher revenes and profits, for all members of the supply chain, reducing communication errors, facilitating information knowledge sharing and increase integration between the supplier and buyer firms. Especially, the relationship and collaboration with customers is very important for eservice innovation. The findings of our study also have implications for managers both of 
$4 \mathrm{PL}$ providers and logistics users. The first is that $4 \mathrm{PL}$ managers must realize the importance of IT capability, as superior IT capability is a source of competitive advantage. The critical role of IT in saving costs, improving service quality and providing a variety of services cannot be ignored. Our study clearly shows the importance of technology orientation in the development of IT capability. 4PL firm managers are therefore recommended to dedicate themselves to the development of an organizational culture that favors IT. A stronger technology orientation in a $4 \mathrm{PL}$ firm helps top business managers to facilitate resource allocation to IT investment and encourages their involvement in IT strategies and planning (Segars and Dean 2001). Well-developed IT capability in a 4PL firm can improve the efficiency, effectiveness and productivity of business operations and thus provide a cost advantage. For example, the adoption of e-business by 4PL firms may help them to expand their customer base and save costs through automated online transactions. Our findings are consistent with other empirical studies that find support for the positive effect of IT capability on cost advantage (e.g., Ravichandran and Lertwongsatien 2005).

Finally, we recommend that the managers of logistics users consider the IT capability of 4PL firms in making outsourcing decisions. Especially, such a consideration is more important for logistics users which aim at long-term relationships with 4PL firms (Knemeyer and Murphy 2004; Cox et al. 2005). The developing strong, long-term partnerships required design managerial components and relationship activities that support the development of intangible connections (trust, commitment, cooperative norms, etc.) with partners.

\section{References}

Banker, S. (2001), E-Business and reverse logistics, December. available at: www.ebizq.net Blumberg, D.R. (1999), Strategic examination of reverse logistics and repair service requirements, needs, market

Bowersox, D.J. \& Daugherty, P.J. (1991), Achieving and maintaining logistics leadership: logistics organisations of the future, Logistics Information Management, Vol. 4 No. 3,pp. 42-7. Brook, IL.

Camm, F. (2001), Environmental management in proactive commercial firms,

Carter, C. R. \& Ellram, L. M. (1998), Reverse Logistics: a Review of the Literature and Framework for Future Investigation, Journal of Business Logistics, vol.19,no.1, pp.85102.

Chapman, R.L. \& Corso, M. (2005), From continuous improvement to collaborative innovation: the next challenge

De Brito, M.P. (2003). Managing Reverse Logistics or Reversing Logistics Management. The Erasmus Research Institute of Management (ERIM) PhD series, N.35, Erasmus university Rotterdam, The Netherlands

De Brito, M.P. \& Dekker R. (2003) A Framework for Reverse Logistics, available at:

De Brito, M.P.; Flapper \& Dekker R. (2002), Reverse logistics: A review of case studies. Econometric Institute Report, 21, pp.1-32.

Dowlatshahi, S. (2000), Developing a theory of reverse logistics, Interfaces, Vol. 30 No. 3, pp. 143-55.

Earl, M. J. (1993), Experiences in Strategic Information Systems Planning: Editor's Comments, MIS Quarterly, Vol. 17, No. 3, pp. 2-3. 
Fleischmann, M.; Bloemhof-Ruwaard J.M.; Dekker R., E. A. van der Laan, J. A. E. E. van Nunen, and L. N. van Wassenhove. Quantitative models for reverse logistics: A review.European Journal of Operational Research, 103:1-17, 1997.

Gattorna, J. (1998), Strategic Supply Chain Alignment: Best Practice in Supply Chain Management, Gower Publishing Limited

Ginter P.M. \& Starling J.M.(1979), Reverse distribution channels for recycling, California Management Review, Vol. 20, No. 3, 1978, pp.72-81.

Goggin K. \& Browne, J.(2000), Towards a taxonomy of resource recovery from end-of-life products. Computers in Industry, 42:177-191

Guiltinan J. \& Nwokoye N. Reverse channels for recycling: an analysis for alternatives and public policy implications in R. G. Curhan (ed.), New marketing for social and economic progress, Combined Proceedings, American Marketing Association, 1974.

Halldo' rsson, A. (2007), "Complementary theories to supplychain management", Supply Chain Management: An International Journal, Vol. 12 No. 4, pp. 284-96.

Kathuria, Ravi, Marugan Anandarajan, and Magid Igbaria (1999), "Linking IT Applications with Manufacturing Strategy: An Intelligent Decision Support System Approach," Decision Sciences, Vol. 30, No. 4, pp. 959-992.

Knemeyer, A.M.; Ponzurick T.G. \& Logar C.M.(2002), A qualitative examination of factors affecting reverse logistics systems for end of life computers, International journal of Physical Distribution \& Logistics Management, Vol.32 Nº, pp455-479

Knemeyer, M.A.; Corsi, T.M. \& Murphy, P.R. (2003), "Logistics outsourcing relationship: customer perspectives", Journal of Business Logistics, Vol. 24 No. 1, pp. 77-109.

Kopichy, R.J.; Berg M.J.; Legg L.; Dasappa V. \& Maggioni C. (1993)," Reuse and re cycling: reverse logistics opportunities", Council of Logistics Management, Oak Brook, IL

Kwok Hung Lau K.H. and Wang Y. (2009) Reverse logistics in the electronic industry of China: a case study, in Supply Chain Management: An International Journal 14/6, 447465

Langley, C.J. Jr, Hoemmken, S., van Dort, E., Morton, J.,Strata, R. \& Riegler, M. (2007), ThirdParty Logistics: Results and Findings of the 12th Annual Study,Reverse logistics in the electronic industry of China

Mukhopadhyay S.K.\& Setaputra R. (2006), The role of 4PL as the reverse logistics integrator. Optimal pricing and return polizie, in International Journal of Physical Distribution $\mathcal{E}$ Logistics Management, Vol. 36 No. 9, 2006pp. 716-729

Physical Distribution \& Logistics Management, Vol. 30 No. 2,pp. 112-27. pp. 95-100.

Pohlen T.L. \& Farris, T. (1992), Reverse logistics in plastics recycling. International Journal of Physical Distribution \& Logistics Management, 22(7):35-47.

RevLog. Revlog, the european working group on reverse logistics. http://www.fbk.eur.nl/OZ/REVLOG/, 1998-

Rodrigue J.P.; B. Slack, \& C. Comtois (2001), Green logistics. In A.M. Brewer, K.J. Button, and Henshe D.A., editors, The Handbook of Logistics and Supply-Chain Management, Handbooks in Transport N. 2. Pergamon/Elsevier, London, "UK", 2001.

Rogers D.S. \& Tibben-Lembke, R.S., (2001), "An examination of reverse logistics practices, " Journal of Business Logistics, vol. 22, pp. 129-148.

Rogers, D.S. \& Tibben-Lembke, R.S. (1999), Going Backwards: Reverse Logistics trend and Practices, Reverse Logistics Executive Council 
Sanders, N.R. "IT Alignment in Supply Chain Relationships: A Study of Supplier Benefits," Journal of Supply Chain Management, (41:2), 2005, pp. 4-13.

Schwartz, B. (2000), "Reverse logistics strengthens supplì chain", Transportation and Distribution, Vol. 41 No. 5,

Skjøtt-Larsen, T. (2000), "Third party logistics - from an interorganizational point of view", International Journal of size, and opportunities", Journal of Business Logistics, Vol. 20 No. 2, pp. 141-59.

Stock J.R. (1992), Reverse Logistics. Council of Logistics Management, Oak Brook, IL,

Stock J.R. . Reverse Logistics. Council of Logistics Management, Oak Brook, IL, 1992

Stock, J.R. (1998), Development and Implementation of ReverseLogistics Programs, Council of Logistics Management, Oak

Thierry M.; M. Salomon; J. A. E. E. van Nunen \& L. N. van Wassenhove (1995), Strategic issues in product recovery management. California Management Review, 37(2):114-135.

Tibben L. \& Rogers R.S. (2002), Differences between forward and reverse logistics in a retail environment, Suply Chain Management, 7 (5), 271-282

Van Hillegersberg, J., Zudiwijk, R., van Nunen, J., \& van Eijk, D. (2001). “Supporting return flows in the supply chain." Communications of the ACM, 44(6), 74-79

Van Hoek, R.I. (1999), "From reverse logistics to green supply chains", Supply Chain Management: An International

Vesstrepen S., Cruijssen F., De Brito M. P., Dullaert W.(2007), “An Exploratory Analysis of Reverse Logistics in Flanders", European Journal of Transport and Infrastructure Research, n. 4, pp. 301-316.

Waddey, L. (2001), "Reverse gear", Operations \& Fulfillment, December, available at: www.opsandfulfillment.com

Williams, Lisa R., Avril N.; Irby D \& Finley T. (1997), Logistics Integration: the effect of Information Technolog, Team Composition and Corporate Competitive Positioning", Journal of Business Logistics, Vol.18, º2, pp.31-54. 


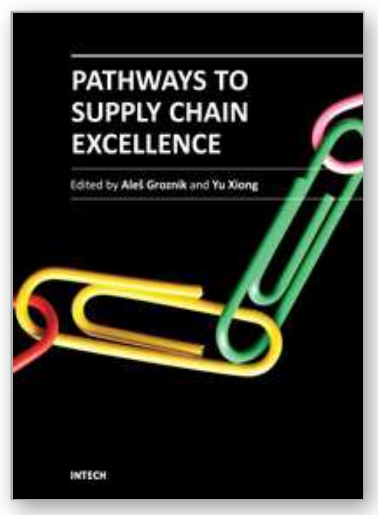

\author{
Pathways to Supply Chain Excellence \\ Edited by Dr. Ales Groznik
}

ISBN 978-953-51-0367-7

Hard cover, 208 pages

Publisher InTech

Published online 16, March, 2012

Published in print edition March, 2012

Over the last decade, supply chain management has advanced from the warehouse and logistics to strategic management. Integrating theory and practices of supply chain management, this book incorporates hands-on literature on selected topics of Value Creation, Supply Chain Management Optimization and MassCustomization. These topics represent key building blocks in management decisions and highlight the increasing importance of the supply chains supporting the global economy. The coverage focuses on how to build a competitive supply chain using viable management strategies, operational models, and information technology. It includes a core presentation on supply chain management, collaborative planning, advanced planning and budgeting system, risk management and new initiatives such as incorporating anthropometry into design of products.

\title{
How to reference
}

In order to correctly reference this scholarly work, feel free to copy and paste the following:

Roberta Pinna and Pier Paolo Carrus (2012). Reverse Logistics and the Role of Fourth Party Logistics Provider, Pathways to Supply Chain Excellence, Dr. Ales Groznik (Ed.), ISBN: 978-953-51-0367-7, InTech, Available from: http://www.intechopen.com/books/pathways-to-supply-chain-excellence/reverse-logistics-andthird-party-logistics-providers-capabilies

\section{INTECH}

open science | open minds

\author{
InTech Europe \\ University Campus STeP Ri \\ Slavka Krautzeka 83/A \\ 51000 Rijeka, Croatia \\ Phone: +385 (51) 770447 \\ Fax: +385 (51) 686166 \\ www.intechopen.com
}

\author{
InTech China \\ Unit 405, Office Block, Hotel Equatorial Shanghai \\ No.65, Yan An Road (West), Shanghai, 200040, China \\ 中国上海市延安西路65号上海国际贵都大饭店办公楼 405 单元 \\ Phone: +86-21-62489820 \\ Fax: +86-21-62489821
}


(C) 2012 The Author(s). Licensee IntechOpen. This is an open access article distributed under the terms of the Creative Commons Attribution 3.0 License, which permits unrestricted use, distribution, and reproduction in any medium, provided the original work is properly cited. 